${ }^{2}$ Gdynia Maritime University

\title{
The Problem of Food Waste in Different Types of Households on the Example of the Residents of Poland and Polish People Residing in the United Kingdom - Pilot Study
}

\begin{abstract}
The objective of this study was comparing the scale of food waste depending on different types of households among Poles living in Poland and in the UK. The research was conducted in the group of 622 persons, whereas 345 persons lived in Poland and 277 were residing in the UK for minimum 2 years, however not longer than 10 years. The respondents were differentiated depending on the type of the household in which they lived: 1-person, 2-person, 3-person, 4-person and more. More than the half of the respondents declared that they had happened to throw away food, whereas these are the "British" Poles who waste food most and who are comprised in 1- and 2-person households. A significant dependence was observed in both studied groups, the more numerous the household was the lesser amount of food was wasted. The mostly wasted food included bread, yoghurts, sausage, fruit and vegetables, regardless of the number of persons in the given household or of the place of residence. Due to the fact that the rate of food waste is so high, it is necessary to find a way to implement new ideas and interventions which would limit the food waste in the households.
\end{abstract}

Key words: waste food, household

JEL Classification: D100, D190, R200

\section{Introduction}

The progressing globalization resulting with changes within the production and consumption zones has caused remarkable changes. Apart from many positive results, the negative effects caused by overproduction and overconsumption in highly developed countries must be mentioned. It is estimated that one third of the food manufactured for consumption by people is lost or wasted all over the world which gives the amount of 1.3 billion ton a year (Food losses and waste..., 2014).

Wasting food has grown within the last decade. The wasted food has been recognized as the cause of the negative economic, social and environmental effects. Eurostat research have found wasted food as one of the most important issues of sustainability which should be resolved promptly. The key idea of the sustainable consumption and production is fundamental understanding of the interaction between the nature and the industrialized society. The definition of the sustainable consumption and production commonly adopted in 2015 within Agenda 2030 is following: A sustainable consumption and production

\footnotetext{
${ }^{1}$ PhD. Eng., Department of Food Commodity Science Medical University of Gdańsk, Dębinki 7, 80-211 Gdańsk; e-mail: skotnicka@gumed.edu.pl; https://orcid.org/0000-0002-0853-0685

${ }^{1}$ MSc Eng., Department of Food Commodity Science Medical University of Gdańsk, Dębinki 7, 80-211 Gdańsk; e-mail: kajakarwowska@gumed.edu.pl; https://orcid.org/0000-0001-7359-2164

${ }^{2}$ Professor, PhD, Department of Commodity Science and Quality Management, Gdynia Maritime University, Morska 81-87, 81-225 Gdynia, e-mail: smiemari@am.gdynia.pl; https://orcid.org/0000-0001-6933-594X
} 
means the use of services and related products, which respond to basic needs and bring a better quality of life while minimizing the use of natural resources and toxic materials as well as the emissions of waste and pollutants over the life cycle of the service or product so as not to jeopardize the needs of further generations and supporting the consumers in making better choices (UNEP, 2010; Zalewska, 2015).

One of the problems impeding the sustainable consumption and production is food waste and common consumerism. This is a complex issue and it should be viewed from different perspectives. In a broader view, it may be a result of inappropriate management in the process of production, distribution, transportation, storage, preparing and losses in households. Food waste means purposefully unused food at every stage of a food chain.

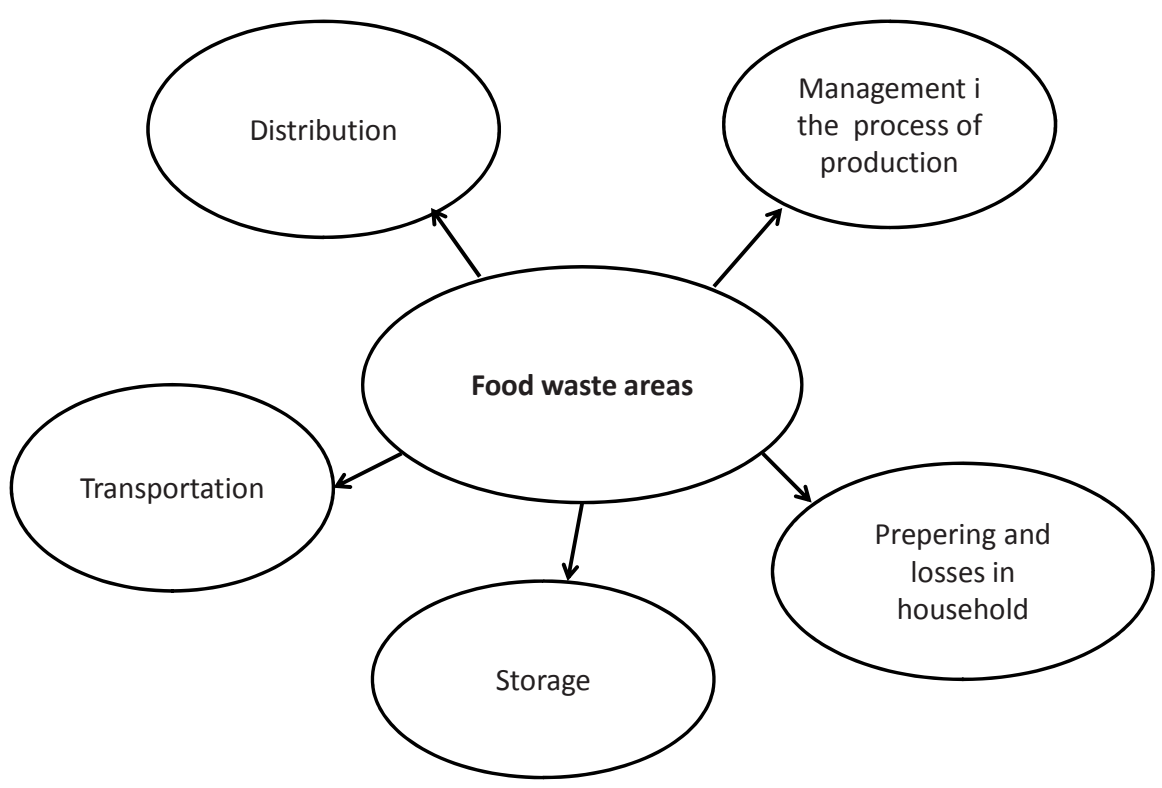

Fig. 1. Food waste areas

Source: own study based on (Śmiechowska, 2016).

Food is lost or wasted throughout the whole food supply chain, from the initial agricultural production to the household consumption. The food losses are the losses of resources used in production, such as soil, water, energy and raw materials, which do not result in the increased level of greenhouse gases emission (Śmiechowska, 2016).

Whereas the household consumption is an essential part of the production and consumption chain, as the consumers of these households make the final choice with regard to the products and services. The lifestyle of these consumers effects the sustainability practices. The factors determining such an attitude are, e.g. increasing income, economic globalization, technological progress, aggressive advertising, decreasing size of households and the society aging process (Caeiro et al., 2012). 
The consumers of the developed countries are one of the greatest sources of food waste. In order to successfully limit the amount of food wasted by the consumers, it is necessary to understand the factors affecting the purchasing decisions and the consumers behaviours related to wasting food.

The research show that the degree of food waste is extremely high (Stanek et al., 2016; Biernat-Jarka and Trębska, 2017). It is estimated that each year a statistical European Union resident wastes $180 \mathrm{~kg}$ of food, whereas $42 \%$ of the amount comes from domestic households. The countries of the best food management include Greece with $44 \mathrm{~kg}$ food losses per one resident. Whereas the country of the highest food waste level are the Netherlands with $579 \mathrm{~kg}$ of unused food. The amount of food waste in Poland is, similarly to UK, $235 \mathrm{~kg}$ per one person a year (Gustavsson et al., 2011; Bilska et al., 2015).

The consumers of the developed countries are one of the greatest sources of food waste. In order to successfully limit the amount of food wasted by the consumers, it is necessary to understand the factors affecting the purchasing decisions and the consumers behaviours related to wasting food. We are able to determine the amount of food waste at each stage of the food chain with high precision (The food we waste, WRAP 2008, Melikoglu et al., 2013). However, in order to take any preventive action it is necessary to discover the reasons of waste and to define whether the mechanisms related to wasting food are the same in all the developed countries. The research on food waste was conducted by many scientists in Poland (Dąbrowska and Janoś-Kresło, 2013, Wrzosek et al., 2014, Lipińska et al., 2016), who have confirmed that the scale of the unused food purchased in Poland is very high. It is, however, not quite certain whether it is connected with nutrition models, life standard or cultural conditions. Many authors claim that it is the place of residence, tradition and the economic factors which determine the frequency and scale of wasting food (Aschemann et al., 2015; Priefer et al., 2016). Therefore, it has been attempted in this study to compare the consumers' attitudes towards wasting food in Poland and among Poles living in the United Kingdom.

The extension of the EU in 2004 has significantly influenced the scale of immigration, the nature and the directions of Polish people's migration, basically for employment reasons. It is for this reason that the UK has become the target country for many Polish immigrants. Higher income and better life standards have caused a strong increase of "new immigration" in this direction. The change of residence place has caused modifications in many areas of daily life (Milewski and Ruszczak-Żbikowska, 2014; Podgórzańska, 2016). The authors have attempted to compare whether the new situation related to leaving Poland has had any effect on the scale of food waste.

Therefore, the objective of this study was discovering the behaviours regarding wasting food of the respondents residing in Poland and Poles who moved to the UK within the last 10 years.

\section{Material and Methods}

The analysis of the problem of food waste was carried out on the basis of the empirical material obtained by means of a survey. The research was conducted in the group of 622 persons, whereas 345 persons lived in Poland and 277 were residing in the UK for minimum 2 years, however not longer than 10 years. The selection was based on nonprobability sampling. The research was conducted on a convenience sample. The respondents were also categorized depending on the type of the household in which they 
lived: 1-person, 2-person, 3-person, 4-person and more. The respondents were also categorized depending on the type of household in which they lived: 1-person, 2-person, 3person, 4-person and more. All the respondents came from an agglomeration above 200000 dwellers and their age was between 25-60 years old. The survey method was used in the research, whereas the respondents were contacted by a direct interview based on a questionnaire. The examined group is described in Table 1.

Table 1. Description of the examined group

\begin{tabular}{l|cc}
\hline Type of household & Poland & United Kingdom \\
\hline 1-person household & 97 & 76 \\
2-person household & 72 & 53 \\
3-person household & 78 & 71 \\
4- and more person household & 95 & 277 \\
Sum & 345 & 71 \\
\hline
\end{tabular}

Source: Authors' own elaboration.

The following research hypotheses were assumed for the achievement of the specific aim:

1. Poles living in the UK throw away food with the same frequency as they do in Poland.

2. The number of persons living in a household does not have any effect on the frequency of wasting away food both in Poland and among Poles residing in the UK.

3. The reasons for throwing out food are the same in Poland and Poles living in the UK.

4. The structure of the wasted food does not depend on the number of persons in a household both among the respondents from Poland and the UK.

The ANOVA test, with the significance level of $\alpha=0.05$, was applied to show the statistical differences between the residents of Poland and Poles residing in the United Kingdom.

\section{Results}

More than a half of the respondents declared that they had happened to throw away food, whereas these were the residents of the UK who wasted the food most and who were comprised in 1-person (27\%) and 2-person (27\%) households (Fig. 2). Among the people living in Poland these are mostly the persons belonging to one person household $(25 \%)$ who also waste food most often. The frequency of food waste in multi-children families is remarkably the lowest one in both analyzed cases. However, among the households in Poland with high number of persons only $3 \%$ declare to waste food frequently. In the UK, on the other hand, $18 \%$ declare to throw away food.

The statistical analysis showed that the test value $F=5.987$ is slightly higher than the threshold, which indicates that there are significant differences between the frequency of throwing away food in Poland and in the UK.

Poles living in the UK tend to throw away food more often than their compatriots living in Poland. Only $7 \%$ of the Poles residing in the UK declare that they never throw 
away food. This rate is remarkably higher in Poland and reaches even $18 \%$. The conducted variance analysis regarding the frequency of wasting food in correlation with the number of persons in the household has indicated the occurrence of statistically significant differences $(\mathrm{p}=0.0053)$. The more persons were in a household the lesser the frequency of food waste was both in Poland and among residents of UK.

The results of our research confirm that we often do shopping without any former planning which, in consequence, causes gathering of food products which require a certain space and conditions for storing. The stock of food unadjusted to the capabilities of the household leads to intensified wasting of food raw materials. As shown by the research implementing an earlier plan for shopping is neither common for Poles nor for Polish people living in the UK.

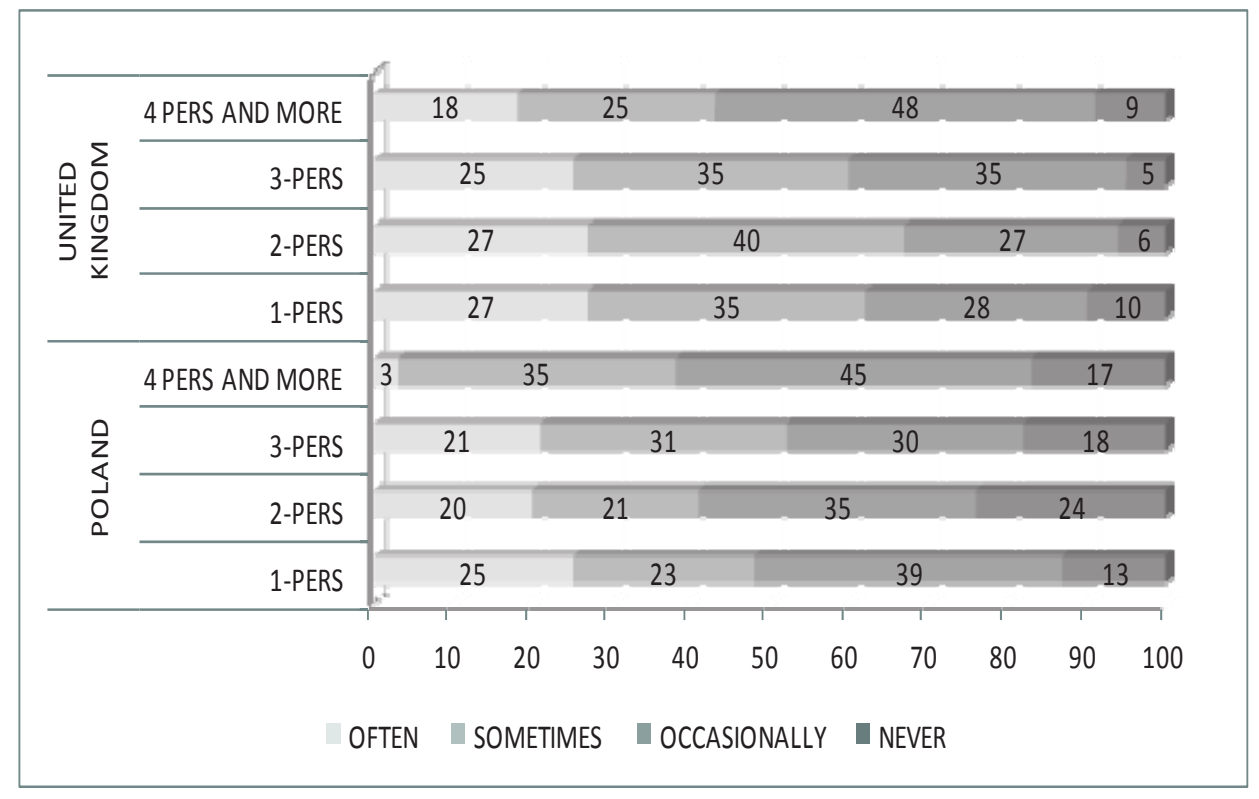

Fig. 2. The frequency of throwing away food in different types of households in Poland and the UK

Source: Authors' own elaboration.

Almost one third of Poles living alone or in a 3-person household maintain that shopping in their households is done always with a shopping list of necessary food products. On the other hand, the families with multiple children plan their shopping more often as even $51 \%$ of them use an earlier prepared shopping list (Fig. 3). In the case of Poles living abroad 4 and more person families (45\%) most often indicate the rational planning as well. Having a prepared list of products while shopping is more common for bigger shopping once a week both in Poland and on the British Isles. Unfortunately, the rate of the respondents doing their shopping impulsively without reasoning is still high and it varies between (38-41\%) for smaller households in Poland and between (30-45\%) in the UK. Although the respondents make purchases once a week without a list, they still buy too much food that will not be used. It should be emphasized that the residents of Poland living in families with multiple children can manage their budget more effectively and plan their 
shopping, are less likely to make impulsive purchases. Only $9 \%$ of them go for a weekly shopping without a shopping list, whereas this rate in the UK reaches (35\%). The persons residing in Poland more often tend to do shopping systematically every day, whereas the persons who moved to the UK declare to prefer doing bigger shopping, however, more rarely regardless of the number of persons living in one household, which indicates a quite different model of providing the household with food.

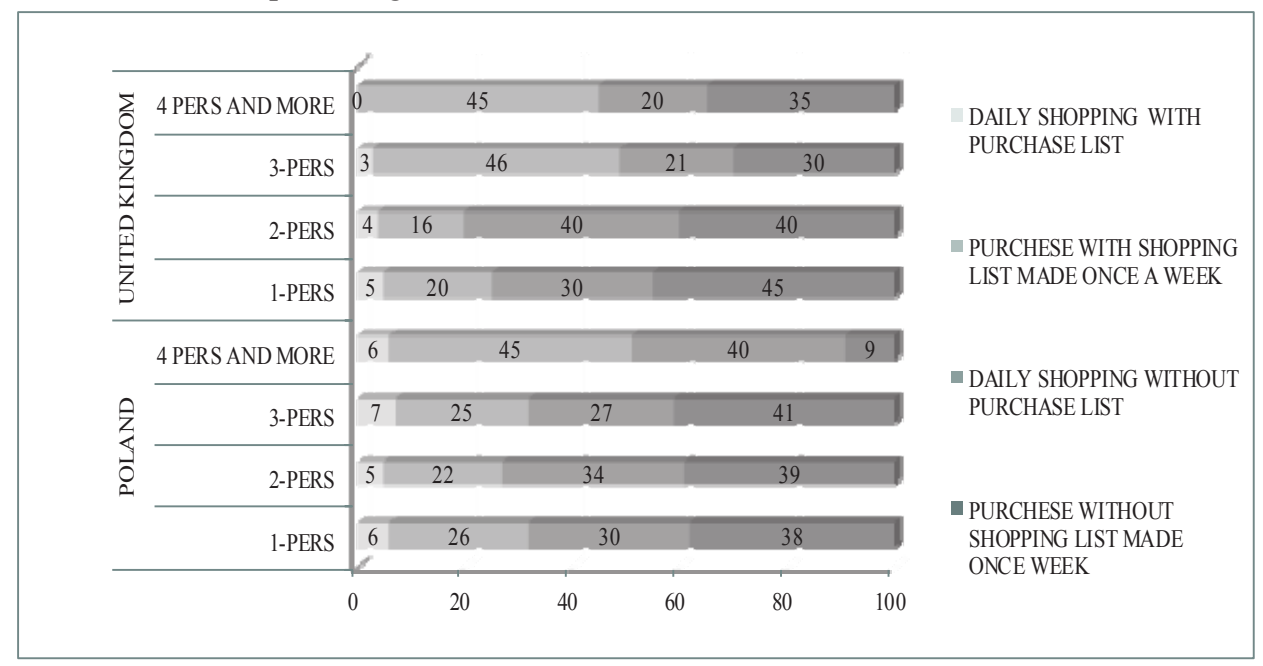

Fig. 3. Shopping habits of the respondents

Source: Authors' own elaboration.

The manner of doing shopping and other habits can directly influence the reasons of wasting food. According to Stefan and co-workers (2013), consumer planning and routine shopping are important predictors of food waste. Planning and purchasing procedures are determined by the moral approach to food waste and perceived control of behavior.

Expiring of food products is the most often mentioned cause of wasting food. The rate of wasted food due to exceeding its shelf life was over $40 \%$. Interesting research results have been observed informing that the expired food is the cause of putting it to the bin in as many as 73\% 4-person households in Poland (Fig. 4). The survey results of multi-children families living abroad are, on the other hand, divergent from the results of the respondents living in Poland. They indicate that the expiration of the product was mentioned as the most frequent reason of food waste, still, throwing away food also takes place in the case of excessive shopping (34\%) which is not adjusted to the real needs. 


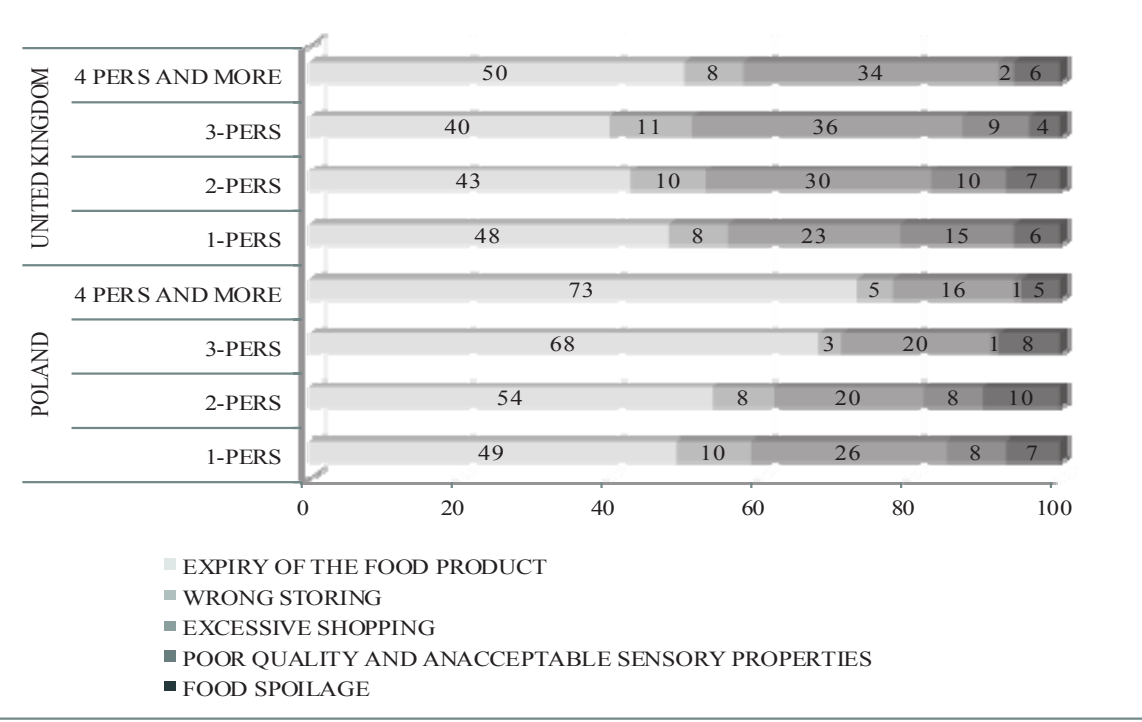

Fig. 4. The causes of wasting food

Source: Authors' own elaboration.

About $8 \%$ of the whole examined population have stated that wrong storing which makes the food deteriorate is one of the reasons of throwing it away. Remarkably much more often persons living in the UK declared that the reason for food wastage are unacceptable sensory properties or inappropriate quality. It refers most frequently to the persons living alone (15\%). The numerous is the household the more rarely it is the bad quality which is the reason of throwing away food. This problem is marginal in Poland as it does not exceed 10\% for 1- and 2-person households, and it is (1\%) for families with more members. The reasons of wasting food reflect the current trend observable in the whole of Europe, regardless of age, education, economic conditions or the size of agglomeration where the people come from. Based on these data the hypothesis has been verified whether the reason of the wasted products in Poland and in UK depends on the number of the household members. In the case of the data from Poland $\mathrm{p}<0.05$ for $\mathrm{F}=4.37$, which means that we reject the zero hypothesis in favor of the alternative hypothesis which indicates that the reason of the food wasted in Poland depends on the number of household members. The statistical analysis of the data of Poles living abroad has indicated that the reasons of the wasted food depends on the size of the family, $p<0.05$. As shown by the research bread is the food product wasted most often regardless of the place of residence or the number of people of the household (Fig. 5, 6). The persons living in 3- and 4-people households declared that bread is the most often wasted product, both in Poland and among the Poles living in the UK. It does not mean that they throw away the biggest amount of bread as compared to households with fewer members. 


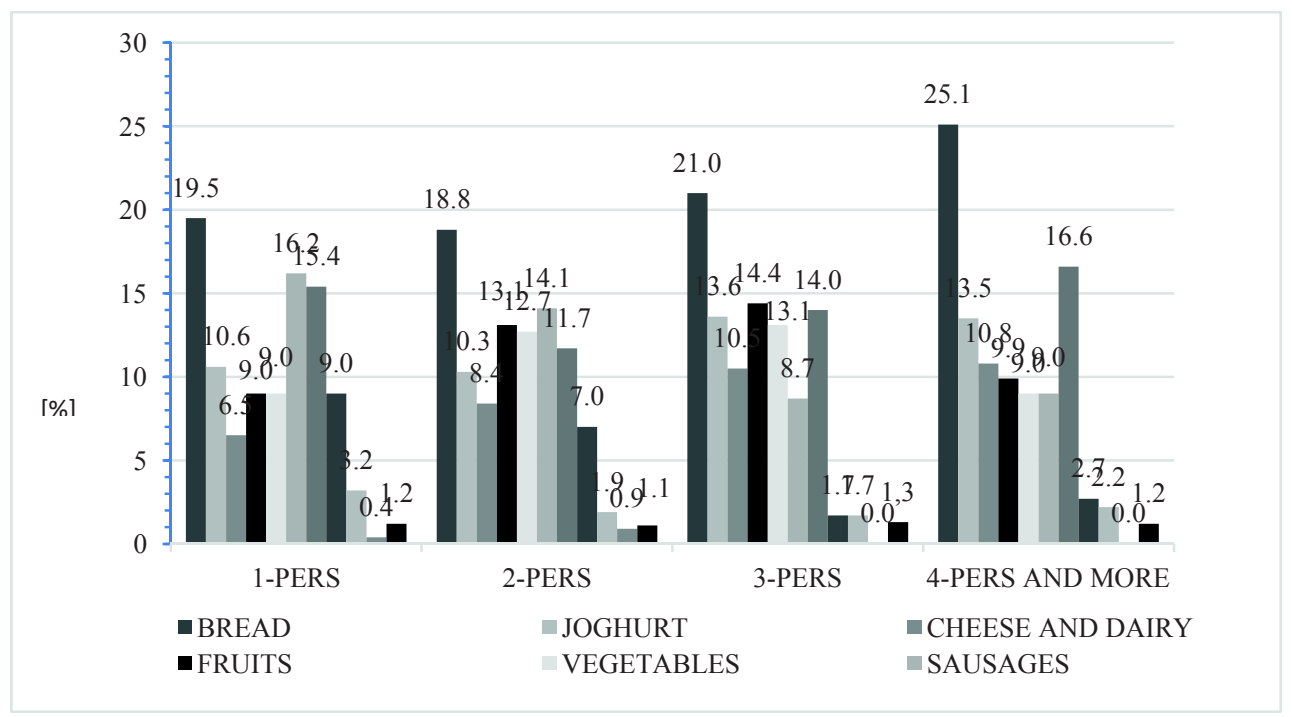

Fig. 5. Products thrown away most often by the respondents living in Poland

Source: Authors' own elaboration.

Meat and the processed meat remains (11-16\%) were the second food most wasted by Polish residents. The differences between the number of persons in a household and the frequency of wasting meat were visible. Poles living in the UK did not mention meat but sausages on the second place in terms of wasting. Disposing of meat in the case of the families with multiple children in UK is, on the other hand, not a common tendency.

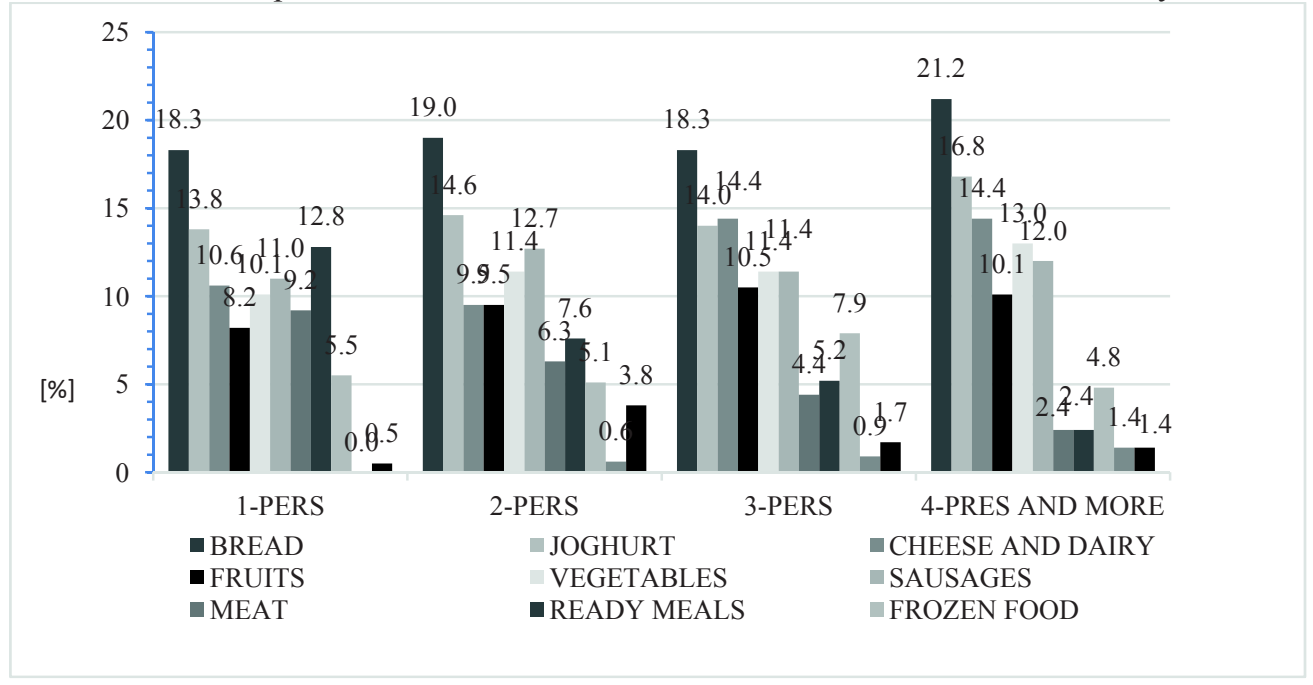

Fig. 6. Products thrown away most often by the respondents living in United Kingdom

Source: Authors' own elaboration. 
Yoghurts are a relatively huge group of products which are wasted frequently; as a specific product group and other dairy products. The sole yoghurts generate losses from $10 \%$ in the case of 1- and 2-person households in Poland, up to $16 \%$ in the families with multiple children living in the UK.

Based on these data the hypothesis has been verified whether the structure of the wasted products in Poland and in UK depends on the number of the household members. In the case of the data from Poland $\mathrm{p}<0.05$ for $\mathrm{F}=2.13$, which means that we reject the zero hypothesis in favor of the alternative hypothesis which indicates that the structure of the food wasted in Poland depends on the number of household members. The statistical analysis of the data of Poles living abroad has indicated that the structure of the wasted food depends on the size of the family, $p<0.05$. Other unanalyzed factors, such as income per person, nutritional preferences, cultural aspects or the accessibility of food products, could have influenced the differentiation within the structure of food waste.

\section{Discussion}

Unfortunately, the worldwide and European data show that highly developed countries generate very high losses of food. It is confirmed by the studies conducted by the Centre for Public Opinion Research in 2016 (Polish people's declarations regarding food waste...2016) and (Parfitt et al., 2010). The research conducted for the purposes of the Federation of Polish Food Banks has indicated that $30 \%$ of the community confess having thrown food away, but this rate is probably significantly higher (Nie marnuj jedzenia..., 2016). Our research shows that food is usually wasted on single-person households in Poland, as well as among Poles living in the UK. On the other hand, the study (Papaj, 2016) has shown that food is wasted most often in 2 person households in Poland and 3 person households in Portugal. It is shown by the research (Stanek et al., 2016; Bilska et al., 2015) that more than a half throw away food. This worrisome phenomenon is especially observed among people living in big cities. It is the dwellers of large urban agglomerations who produce most waste (Secondi et al., 2015). The surveyed respondents also lived in cities of over 200,000 inhabitants, which could determine the results of the research. Perhaps it would be necessary to compare the results of respondents from smaller cities and villages

The conducted pilot study has shown that the Poles living in the UK more often waste food as compared to the Pole living in Poland. This can be a signal that the radical change of the residence place and the hazards related to its cause that immigrants cope less skillfully with the management of their budget and planning of their daily expenses, which also confirms in their research (Seshan and Yang, 2014). Poland more and more often becomes the place of residence for immigrants, especially from the East. It seems substantiated to verify whether similar tendencies regarding food waste are also observable in Poland.

As shown by the research many authors, the food price in relation to the income is one of the basic causes of the food loss in a household (Evans et al., 2004; Koivupuro et al., 2012; Nahman et al., 2012). Multi-children families most often waste the cheapest products from the basic goods basket, which was also confirmed in our research Generally, however, we most often get rid of the food that goes off quickly. The reason can be either excessive shopping or bad storing conditions (Press release: Industry recommendations unveiled to reduce household food waste, 2010). 
The stock of food unadjusted to the capabilities of the household leads to intensified wasting of food raw materials. Our research has shown that we rarely use a pre-prepared shopping list, which can generate a problem of food waste in households Similar results have been obtained by (Beretta et al., 2013; Graham-Rowe et al., 2014; Ponis et al., 2017). The research has shown that the problems with the domestic budget do occur regardless of the social and economic status, education, age or place of residence. Rational planning is one of the elements of prevention in the food waste limiting strategy (Trichopoulou et al., 2003; Dąbrowska and Janoś-Kresło, 2013).

A number of initiatives aiming at fighting against food waste at consumer's level have been presented all over the world. However, a complex analysis and categorization of the most important ones has not been proposed until this day. As shown by (Ganglbauer et al., 2013) wasting food is an unintended effect of many consumption moments scattered in space and time. The highest share of food waste in households constitute the leftovers on the plates or the leftovers from cooking or wrong storing of ready meals. (Van Grade et al., 1987, Guthrie and Buzby 2002, Engström and Carlsson-Kanyama 2004) have come to similar conclusions. It has been confirmed in the research that the leftover food constitutes about $13 \%$ of the food produced both at home and in restaurants. The authors indicate that the issue of plate leftovers and no possibility to use them is a serious problem also in Poland (Dąbrowska and Janoś-Kresło, 2013).

The results our research coincide with the social analysis conducted in 2011 in Poland (Czapiński, Panek, 2011). According to the research conducted by (Mena et al., 2011) among the residents of UK and Spain, the food wasted mostly involved bread and oils, and in the next turn, sandwiches, yoghurts and ready salads, which has been partially confirmed by our surveys. At the same time the research (The food we waste, WRAP 2008, United Kingdom) shows that eggs are on a high position among the wasted food in the UK, which might be related with the tradition of eggs consumption in the cuisine and culture of AngloSaxon countries. It also confirms that the immigrants coming to the Isles do not acquire the nutritional habits so quickly in their new home country. The comparative studies of both countries were subject of analyses of Papaj in (2016). The structure of wasted food of the Polish and Portuguese was compared then. The report has shown that Polish people more often throw away meat than the Portuguese, however, they do not throw away fish at all. Fish is very expensive in Poland and not easily accessible, which is not the case in the coastal Portugal. This analysis shows at the same time that the structure of wasting food also depends on the place of residence and the manner and possibility of providing food.

When combined with other milk based products the share of the waste is about $1 / 4$ of the whole wasted food. Fruit and vegetables belong to the products which often land in the bin too. We buy too much of them and they are quickly perishable products as reported by (Eriksson et al., 2012). They analyzed food losses and the scale of waste in Sweden. According to (Garfield, 2016) in Business Insider it is just the fruit and vegetables which constitutes the biggest group of food products wasted by the British. Both groups declared throwing away ready meals, frozen foods and fish in a lesser degree.

Although, a tendency can be observed that the more persons are in the household, the more rarely such type of food is wasted. It is probably connected with different nutritional models where the nutritional situation is reflected by the life standard and satisfying the needs. For this reason the amounts of bread as the basic dietary component constitute such a high rate for the families with multiple children living in Poland. According to Śmiechowska (2016), the losses of the unconsumed bread within one month in 4-person 
households varies depending on the size of the city from 0.7 to $2.1 \mathrm{~kg}$, whereas the consumption in smaller households is higher and is even up to $3.7 \mathrm{~kg}$, however, the frequency of wasting bread might be quite different.

\section{Conclusion}

The aim of this study was to examine the behavior of Polish citizens and the Poles living in the United Kingdom with regard to food waste. The presented studies broaden the knowledge on food waste in Poland but also with regard to the Poles living in UK. The study results have indicated certain differences between the examined populations, therefore, the following conclusions have been drawn:

1. Poles living in the UK waste food more often than the people living in Poland.

2. The number of persons in a household has an effect on the frequency of wasting food, both in Poland and among the residents of the UK. This creates a rule that the more persons are in a household the less frequently food is wasted.

3. Rational planning of shopping is not a common habit in each group of the examined population.

4. The most common reason for throwing out the food is the expiration date both in Poland and among Poles residing in the UK, but in most of the configurations, bread is usually wasted.

5. The structure of wasted food is different depending on the place of residence.

6. The above results confirm that the persons who have immigrated cope less skillfully with planning of their shopping and, by the same, they more often waste food, which should be particularly monitored in terms of the immigration movements.

Although the problem of food waste has been known for years, still, the methods to solve it remain insufficient. It seems that the education programs supporting the management of the unused food or the shopping plan applications for mobile devices do not give the desired results. It is supposed that it is the consumers' attitudes which must change. Still, in order to change the people's behavior in respect of food waste, the efforts should be made towards providing the consumers with skills and tools to manage their actions related with the management of the unused food.

\section{References}

Aschemann-Witzel, J., de Hooge, I., Amani, P., Bech-Larsen, T., Oostindjer, M. (2015). Consumer-Related Food Waste: Causes and Potential for Action. Sustainability, 7(6), 6457-6477.

Beretta, C., Stoessel, F., Baier, U., Hellweg, S. (2013). Quantifying food losses and the potential for reduction in Switzerland. Waste Management, 33(3), 764-773.

Biernat-Jarka, A., Trębska, P. (2017). Problem marnotrawstwa w perspektywie unijnej polityki bezpieczeństwa żywności (Problem of Food Waste in the Policies of the European Union Food Security). Roczniki Stowarzyszenia Ekonomistów Rolnictwa i Agrobiznesu, 19(3), 24-28.

Bilska, B., Grzesińska, W., Tomaszewska, M., Rudziński, M. (2015). Marnotrawstwo żywności jako przykład nieefektywnego zarządzania w gospodarstwach domowych (Food waste as an example inefficient management in households). Roczniki Stowarzyszenia Ekonomistów Rolnictwa i Agrobiznesu, 17(4), 39-43.

Caeiro, S., Ramos, T. B., Huisingh, D. (2012). Procedures and criteria to develop and evaluate household sustainable consumption indicators. Journal of Cleaner Production, 27, 72-91. 
Czapiński, J., Panek, T. (2015). Diagnoza Społeczna. Warunki i Jakość Życia Polaków (Social Diagnosis 2015 Objective and Subjective Quality of Life in Poland). Available at: http://www.diagnoza.com/data/report/ report_2015.pdf

Dąbrowska, A., Jaroś-Kresło, M. (2013). Marnowanie żywności jako problem społeczne (Food Waste as a Social Problem). Handel Wewnętrzny, 4(345), 14-26.

Deklaracje Polaków dotyczące marnowania żywności (Declarations of Poles regarding food waste). Komunikat z badań nr 115/2016. CBOS, Warszawa 2016. Available 15.09.2018 at: https://www.cbos.pl/SPISKOM.POL/ 2016/K_115_16.pdf.

Engström, R., Carlsson-Kanyama, A. (2004). Food losses in food service institutions Examples from Sweden. Food Policy, 29(3), 203-213.

Eriksson, M., Strid, I., Hansson, P.A. (2012). Food losses in six Swedish retail stores: Wastage of fruit and vegetables in relation to quantities delivered. Resources, Conservation and Recycling, 68, 14-20.

Evans, M.D., Dizdaroglu, M., Cooke, M.S. (2004). Oxidative DNA damage and disease: induction, repair and significance. Mutation Research/Reviews in Mutation Research, 567(1), 1-61.

Food losses and waste in the context of sustainable food systems. A report by the high level panel of Experts on Food Security and Nutrition, June 2014. Available 15.09.2018 at: http://www.fao.org/3/a-av037e.pdf.

Ganglbauer, E., Fitzpatrick, G., Comber, R. (2013). Negotiating food waste. ACM Transactions on ComputerHuman Interaction, 20(2), 1-25.

Garfield, L. (2016). The world wastes a staggering amount of food - here's the breakdown by type, Business Insider Report.

Graham-Rowe, E., Jessop, D.C., Sparks, P. (2014). Identifying motivations and barriers to minimising household food waste. Resources, Conservation and Recycling, 84, 15-23.

Gustavsson, J., Cederberg, C., Sonesson, U., Van Otterdijk, R., Meybeck, A. (2011). Global Food Losses and Food Waste: Extent, Causes and Prevention, FAO, Rome, Italy.

Guthrie, J.F., Buzby, J.C. (2002). Several Strategies May Lower Plate Waste in School Feeding Programs. Food Review, 25(2), 36 .

Koivupuro, H.K., Hartikainen, H., Silvennoinen, K., Katajajuuri, J. M., Heikintalo, N., Reinikainen, A., Jalkanen, L. (2012). Influence of socio-demographical, behavioural and attitudinal factors on the amount of avoidable food waste generated in Finnish households. International Journal of Consumer Studies, 36(2), 183-191

Lipińska, M., Tomaszewska, M., Kołożyn-Krajewska, D. (2016). Problem strat w łańcuchu żywnościowym na podstawie transportu wyrobów mleczarskich (The problem of losses in the food chain on the example of transportation of dairy products). Zeszyty Problemowe Postepów Nauk Rolniczych, 584, 61-70.

Melbye, E.L., Onozaka, Y., Hansen, H. (2017). Throwing it all away: Exploring affluent consumers' attitudes toward wasting edible food. Journal of Food Products Marketing, 23(4), 416-429.

Melikoglu, M., Lin, C.S.K., Webb, C. (2013). Analysing global food waste problem: Pinpointing the facts and estimating the energy content. Central European Journal of Engineering, 3(2), 157-164.

Mena, C., Adenso-Diaz, B., Yurt, O. (2011). The causes of food waste in the supplier-retailer interface: Evidences from the UK and Spain. Resources, Conservation and Recycling, 55(6), 648-658.

Milewski, M., Ruszczak-Żbikowska, J. (2008). Motywacje do wyjazdu, praca, więzi społeczne i plany na przyszłość polskich migrantów przebywających w Wielkiej Brytanii i Irlandii (Migration motives, work, social relations and plans for the future of polish migrants in the UK and Ireland). CMR Working Papers, $35,93$.

Nahman, A., de Lange, W., Oelofse, S., Godfrey, L. (2012). The costs of household food waste in South Africa. Waste Management, 32(11), 2147-2153.

Nie marnuj jedzenia. (2016). Raport cz.1. Federacja Polskich Banków Żywności, Warszawa. Available 09.09.2018 at: bzsos.pl/wp-content/uploads/2016/.../Raport-Nie-marnuj-jedzenia-2016-_-część-1-.pdf.

Papaj, K. (2016). Food waste-Policies, initiatives and consumer behaviour. Case study: Poland and Portugal. Resources, Conservation and Recycling, 109, 155-165.

Parfitt, J., Barthel, M., Macnaughton, S. (2010). Food waste within food supply chains: quantification and potential for change to 2050. Philosophical Transactions of the Royal Society of London. Series B, Biological Sciences, 365(1554), 3065-3081.

Podgórzańska R. (2016). Emigracja Polaków do Wielkiej Brytanii w latach 2004-2016. Implikacje dla stosunków polsko-brytyjskich (The Polish Emigration to Great Britain in the Years 2004-2016. Implications for the Polish-British Relations). Przeszlość Demograficzna Polski, 38(3), 186-204.

Ponis, S.T., Papanikolaou, P.A., Katimertzoglou, P., Ntalla, A.C., Xenos, K.I. (2017). Household food waste in Greece: A questionnaire survey. Journal of Cleaner Production, 149, 1268-1277.

Press release: Industry recommendations unveiled to reduce household food waste, WRAP, 2010. Available 30.09.2018 at: http://www.wrap.org.uk/.../agreeing-attribution-factor-wraps-work-redu... 
Priefer, C., Jörissen, J., Bräutigam, K.R. (2016). Food waste prevention in Europe - A cause-driven approach to identify the most relevant leverage points for action. Resources, Conservation and Recycling, 109, 155-165.

Secondi, L., Principato, L., Laureti, T. (2015). Household food waste behaviour in EU-27 countries: A multilevel analysis. Food Policy, 56, 25-40

Seshan, G., Yang, D. (2014). Motivating migrants: A field experiment on financial decision-making in transnational households. Journal of Development Economics, 108, 119-127.

Śmiechowska, M. (2016). Marnotrawstwo żywności a zrównoważona konsumpcja w gospodarstwach domowych. Próba oszacowania marnotrawstwa pieczywa (Food Wastage and Sustainable Consumption in Households. An Attempt to Estimate Bread Wastage). Handel Wewnętrzny, 1(360), 151-160.

Stanek, P., Sawicka-Zugaj, W., Adamczyk, W., Bańkowska, A., Widz P. (2016). Problem marnowania żywności w opinii mieszkańców Lublina (The problem of wasting food in the opinion of Lublin inhabitants). Annales UMCS SECITO EE ZOOTECHNICA, 34(4), 77-85.

Stefan, V., van Herpen, E., Tudoran, A.A., Lähteenmäki, L. (2013). Avoiding food waste by Romanian consumers: The importance of planning and shopping routines. Food Quality and Preference, 28(1), 375381.

The food we waste, WRAP 2008. Available 1.10.2018 at: http://wrap.s3.amazonaws.com/the-food-we-waste.pdf.

Trichopoulou, A., Naska, A. (2003). European food availability databank based on household budget surveys: The Data Food Networking initiative. The European Journal of Public Health, 13(suppl 3), 24-28.

UNEP 2010, ABC of SCP, Clarifying Concepts on Sustainable Consumption and Production. Available 1.10.2018 at: http://www.unep.org/resourceefficiency/Portals/24147/scp/go/pdf/ ABC_EGLISH.pdf.

Van Garde, S.J., Woodburn, M.J. (1987). Food discard practices of householders. Journal of the American Dietetic Association, 87(3), 322-329.

Wrzosek, M., Bilska, B., Kołożyn-Krajewska, D., Krajewski, K., Kondraszczuk, A. (2014). Określenie skali i przyczyn strat żywności w handlu detalicznym na przykładzie mleka i jego przetworów (Determining scale and causes of food losses in trade exemplified by milk and its products). Żywność, Nauka, Technologia, Jakość, 2(93), 225-238.

Zalewska, M. (2015). Zrównoważona produkcja i konsumpcja - nierówności w krajach Unii Europejskiej (Sustainable Consumption and Production - Inequalities in the European Union). Nierówności Spoleczne a Wzrost Gospodarczy, 42(2), 140-151.

For citation:

Skotnicka M., Karwowska K., Śmiechowska M. (2018). The Problem of Food Waste in Different Types of Households on the Example of the Residents of Poland and Polish People Residing in the United Kingdom - Pilot Study. Problems of World Agriculture, 18(3), 282-294;

DOI: 10.22630/PRS.2018.18.3.86 